\title{
Effects of food quality on Melolontha spp. adults
}

\author{
Danuta Woreta, Robert Wolski $\bowtie$, Stawomir Lipiński, Miłosz Tkaczyk
}

Forest Research Institute, Department of Forest Protection, Sękocin Stary, Braci Leśnej 3, 05-090 Raszyn, Poland, phone: +48 22 7150551, e-mail: R.Wolski@ibles.waw.pl

\section{Abstract}

The paper presets the results of the study on the life span, survival, body weight and fecundity of cockchafer (Melolontha spp.) adults feeding on the leaves of Betula pendula Roth., Quercus robur L., Q. rubra L., Acer platanoides L., Tilia cordata Mill. and Pinus silvestris L. inflorescences. The life span and body weight of adults, as well as female fertility were examined in the years 2015, 2016 and 2017. In 2015, the tested common cockchafer (Melolontha melolontha L.) adults and forest cockchafer (Melololntha hippocastani F.) adults were fed on B. pendula., Q. robur and P. silvestris. In 2016, forest cockchafer adults were fed on B. pendula, Q. robur, Q. rubra, T. cordata, and in 2017 - on B. pendula., Q. robur T. cordata and A. platanoides. Adults of both species feeding on $Q$. robur were treated as the control. Adult specimens observed under laboratory conditions were collected in the field, shortly after leaving their overwintering sites in the soil. Our results showed that feeding on the leaves of Q. robur and Q. rubra had the greatest positive effects on the life span, body weight and fecundity of the studied cockchafer adults. M. melolontha females reared on the leaves of $B$. pendula laid no eggs. The leaves of A. platanoides constituted an adequate food source for the development of M. hippocastani. P. silvestris inflorescences proved to be the right food only for M. melolontha females. M. hippocastani adults feeding on T. cordata and B. pendula were characterized by a short life, decreasing body weight in the first days of observation and low fertility.

\section{KEY WORDS}

common cockchafer, mortality, food quality, forest cockchafer, forest pests, relative growth rate

\section{INTRODUCTION}

Common cockchafer Melolontha melolontha L. and forest cockchafer Melolontha hippocastani F. are the major pests of forest, agricultural and orchard crops. Feeding of cockchafer larvae (grubs) on the roots of trees and shrubs results in plant deteriorating, and in the case of younger crops - severe grub feeding can lead to plant death. Plant damage increases with the growth of grubs, as the older they are the thicker plant roots are damaged due to grub voracious feeding. Supplementary adult feeding takes place in larch crowns and those of deciduous trees. Cockchafer adults do not damage foliage, thus do not threaten host plants as much as grubs injure the roots of seedlings, nevertheless, feeding of large adult populations in tree crowns can increase host plant susceptibility to a range of harmful environmental factors.

As said by literature on the subject of forest protection, forest managers have long tried to secure forest crops against cockchafers in a range of ways. In the past, 
mechanical and prophylactic methods to reduce damage were most commonly used (Woreta 1997). Shaking adults off the tree crowns to catch and kill was widely used in Poland in the 1930s (Maciejowski 1936; Petrykowski 1937). Also, the method often used was to pull out grubs from the soil prior to planting (Remiszewski 1899). At a time when chemicals were not yet known, attempts were made to reduce pest harmfulness by planting certain plant species - as observed not selected by cockchafers for feeding. It was recommended, for example, to plant nursery quarters with black alder on "heavier soils" and on "lighter soils" - with white alder (Różyński 1926). Furthermore, sites severely affected by grub feeding were to be sown with buckwheat, lupine and other legumes, because it was noted that grubs did not feed on the roots of these species. Afterwards, planting of needed crops was performed as the soil was released from grubs.

In Poland, at some stage in a severe cockchafer outbreak in the1950s, chemical treatments with chlorinated hydrocarbons were introduced into forest protection practice to control harmful insects. The use of insecticides from the group of chlorinated hydrocarbons in forestry, agriculture and horticulture for many years could have contributed to a significant reduction of the risk due to cockchafers in the 1980s. Then, risk reduction in forested areas could also be a consequence of afforestation of clear-cuts, wastelands, fallows, glades and sparsely wooded areas. In the years 1980-1993, the risk was maintained at a low level, however cockchafer attacks still affected nurseries and not economically important areas within forest plantations (Woreta 1994).

Gradual replacement of toxic chemicals with those more environment-friendly (Woreta 2015, 2016a), and the withdrawal of nearly all so far used insecticides have contributed to the fact that the risk due to cockchafer increasing populations has been at a high level for last several years. Until recently, the only effective way to combat this pest was insecticide treatment (Malinowski 2003). The restrictions introduced by the EU's and national legislation as for chemical treatments, resulting from concern for the environment, increased interest in other, non-chemical methods of crop protection, including those silvicultural, agricultural and biological (Skrzecz et al 2014, Malinowski 2010). The present study aimed at broadening knowledge about the effects of food type on cockchafer development.

\section{Material AND MethodS}

\section{Biological material}

Females and males of common and forest cockchafers were used in the experiments. Research on the effect of individual plant species on cockchafer development was carried out on the leaves of pedunculate oak (Quercus robur L.), red oak (Quercus rubra L.), silver birch (Betula pendula Roth.), small-leaved lime (Tilia cordata Mill.), Norway maple (Acer platanoides L.), as well as on inflorescences of Scots pine (Pinus silvestris L.).

\section{Research methodology}

\section{Cockchafer endurance on various plant species}

The cockchafer life span, body weight gain in the first week of observations and female fertility were examined in the years 2015-2017. Adult cockchafer specimens were collected in the field, soon after they left their overwintering sites in the soil. In 2015, forest cockchafer imagines were collected in the Forest District Jabłonna (Regional Directorate of State Forests Warszawa), and those of common cockchafer - from the Forest District Brzezina (RDSF Łódź). In 2016, under field conditions, there were found only forest cockchafer adults swarming in the Forest District Wyszków (RDSF Warszawa). Likewise, in 2017, only forest cockchafer adults were collected in the Forest District Kozienice (RDSF Radom). Experimental plants were collected within the area of the Forest District Chojnów (RDSF Warszawa).

In 2015, the assessment of plants in terms of their effects on common and forest cockchafer adults was carried out on the leaves of pedunculate oak, silver birch and on inflorescences of Scots pine. Scots pine inflorescences were available for forest cockchafer adults a week later than other tested plants, for the reason that at the time of their emergence, no blooming was observed in Scots pine yet. Therefore, the collected forest cockchafer adults were stored in a climate chamber at a temperature $7^{\circ} \mathrm{C}$ until pine inflorescences developed. Common cockchafer adults emerged later, at the time when pine inflorescences were already developed.

In 2016, the observations included pedunculate oak, as the control plant, as well as red oak, silver birch and small-leaved lime. Then, on the leaves of the chosen plant species, there was observed performance of forest cockchafer adults only. In 2017, the observations were carried out on forest cockchafer adults feeding on the 
leaves of pedunculate oak, silver birch, small-leaved lime and Norway maple.

The design of all the experiments on cockchafer life span and body weight gain was consistent, i.e.: each plant species was placed in 3 containers, with 5 females and 5 males of forest cockchafer/container or 3 females and 3 males of common cockchafer/container.

In each container, host plants' shoots were replaced with fresh ones twice a week, and then fresh water was poured into the dishes. At that time, adult body weight and mortality were recorded. In further analysis, there were used data on adult body weight documented on the first day of the experiment and that after seven days of feeding on the investigated plants. The body weight was determined with an accuracy of $0.001 \mathrm{~g}$ using an $\mathrm{AD}$ 300 scale (Axis Ltd., Gdańsk, Poland).

The first stage of the female fertility study was rearing females and males on the leaves of the studied plants. The leaved shoots of each plant species tested were placed in 3 containers, and 6 adult cockchafers (4 females and 2 males) were placed in every container. After 10 days, altogether 10 females were selected from each host plant. Then they were placed in the containers with sand and the host plant on which they fed so far was placed in a pot with water. After about 3 weeks, the sand search began to determine the number of eggs laid by females.

All the observations were carried out in a part of the greenhouse covered from all sides by a net fixed under the roof.

\section{Statistical analysis}

Relative growth rate (RGR), which was calculated according to the formula by Lazarevic et al. (2002), was used to assess the change in the weight of cockchafer adults:

$$
R G R=\frac{\left(M_{t}-M_{0}\right)}{\left(T_{t-0} \times M_{0}\right)}
$$

where:

$M_{o}$ and $M_{t}$ - initial and final body weight (g),

$T_{t-o} \quad-$ number of days between initial and final weighing.

RGR was calculated for the period of about 1 week from the beginning of rearing, as then insect feeding was the most intense. In order to compare the average RGR achieved by the examined specimens, one-way ANOVA was used, and if ANOVA assumptions were not met, the Kruskal-Wallis non-parametric test with the comparison of the middle rank values was performed.

\section{Results}

\section{Cockchafer life span}

Experimental year: 2015

Forest cockchafers were placed on pine inflorescences on May 7 (Fig. 1). The results showed that females who were feeding on Scots pine inflorescences lived comparatively the shortest -4 weeks, nevertheless, for the first two weeks $100 \%$ of the females survived on this plant species. The females feeding on the leaves of pe-

A

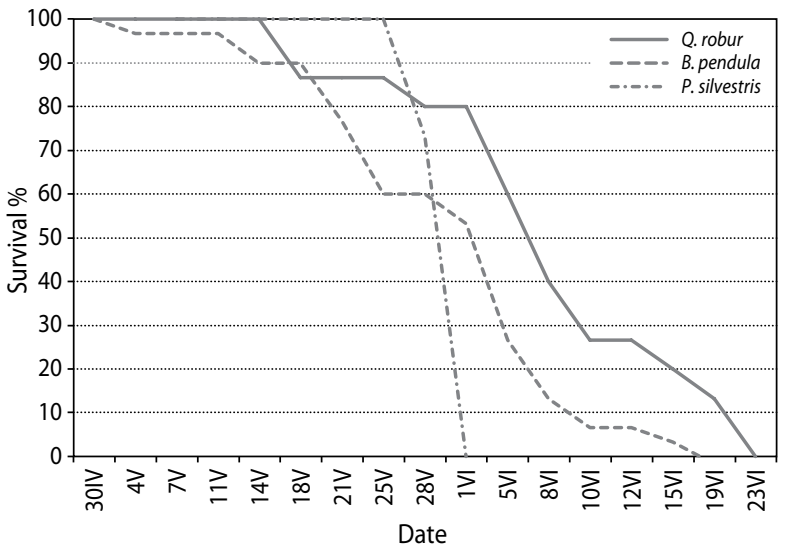

B

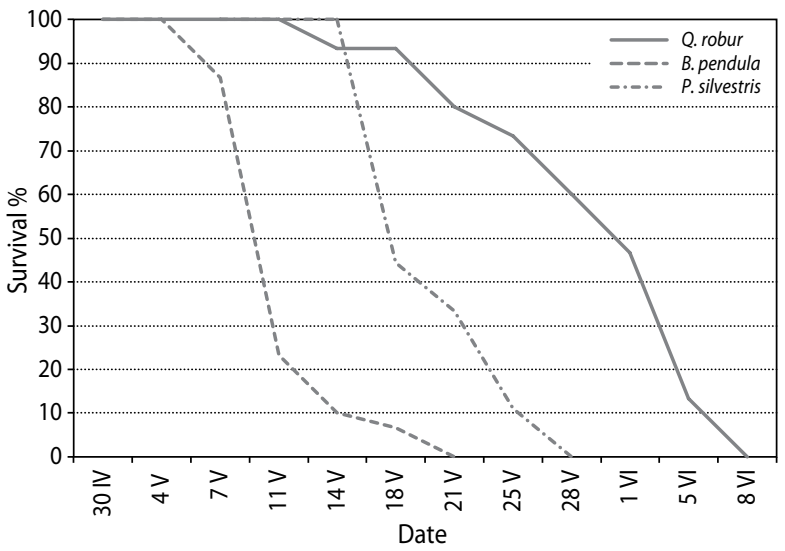

Figure 1. Survival of forest cockchafer adult females (A) and males (B) on the studied plants in 2015 
dunculate oak lived for almost 8 weeks and those on the leaves of silver birch lived a few days shorter (Fig. 1A). Males lived the longest on oak leaves (almost 6 weeks) (Fig. 1B) and those feeding on silver birch and Scots pine lived for about 3 weeks.

There were no statistically significant differences between the life span of forest cockchafer females feeding on oak and birch leaves, however, the average life span of the females on these plant species differed significantly from the life span of the females feeding on Scots pine inflorescences (Fig. 2A). The average life span of the males feeding on silver birch leaves and Scots pine inflorescences did not differ significantly. The longest-lived males fed on oak leaves, and in this case the average life span differed significantly from that of the rest of males observed (Fig. 2B).

\section{A}

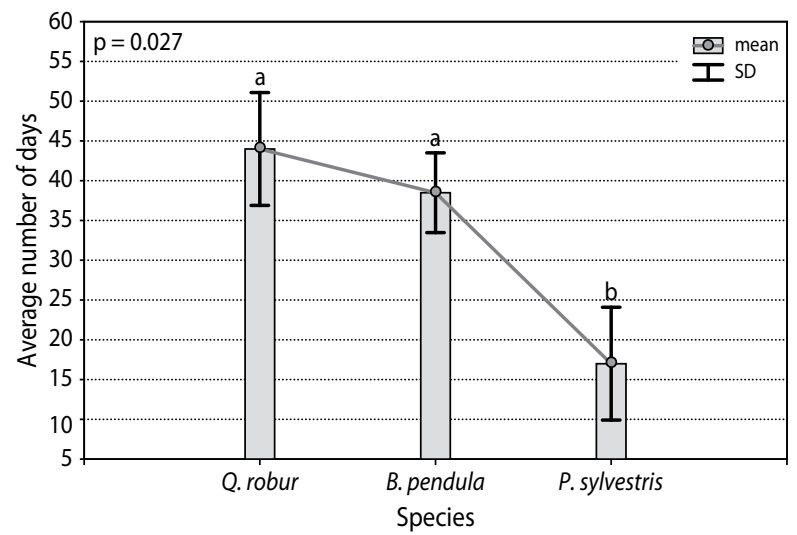

B

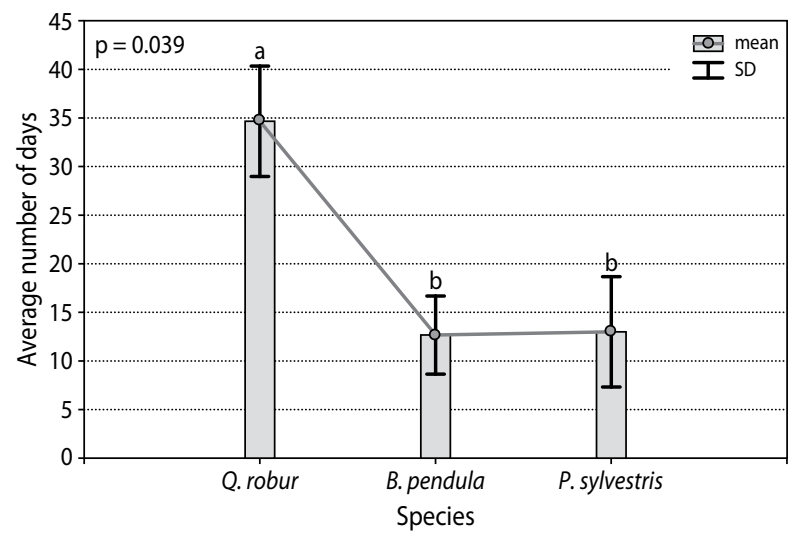

Figure 2. Average life span of forest cockchafer adult females (A) and males (B) examined in 2015
Common cockchafer females lived the longest (over 8 weeks) on the leaves of pedunculate oak, whereas on the leaves of silver birch - 21 days shorter (Fig. 3A). The females feeding on of Scots pine lived only 2 days shorter when compared to those feeding on oak leaves. Male survival rates varied, depending on the host plant tested: the males lived much longer on the leaves of pedunculate oak when compared to those feeding on other plant species (Fig. 3B).

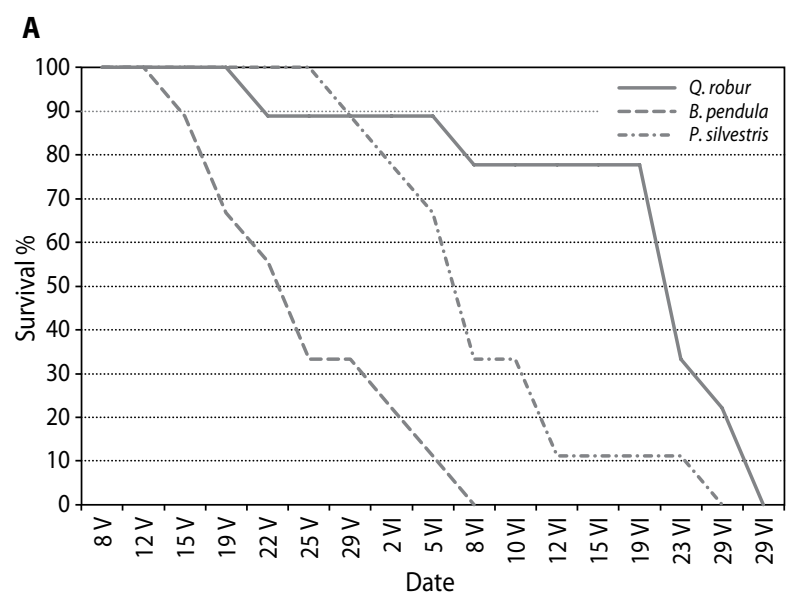

B

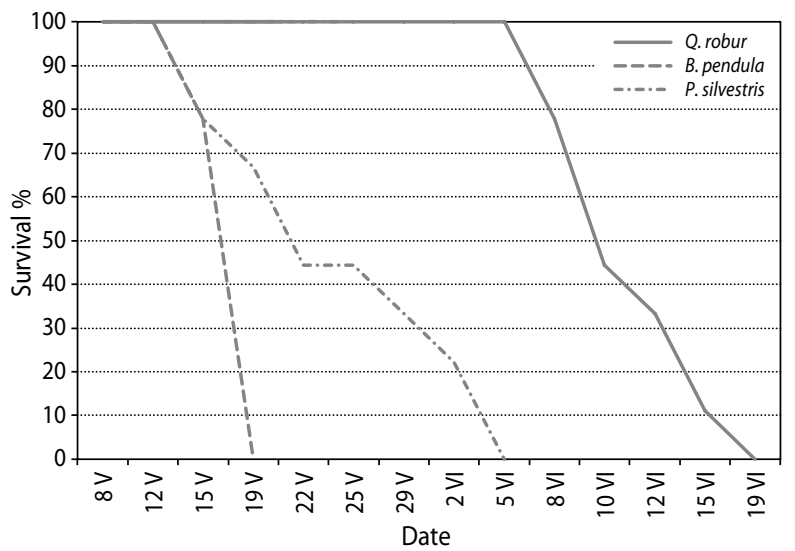

Figure 3. Survival of common cockchafer adult females (A) and males (B) on the studied plants in 2015

The average life span of both common cockchafer females and males was the shortest in the case of silver birch diet (Fig. 4). There were no statistically significant differences between the average life span of the females feeding on oak leaves and Scots pine inflo- 
rescences. The males lived the longest on the leaves of pedunculate oak - their average life span differed significantly from that in the males feeding on other plant species examined. No significant differences were found between the average life span of the males feeding on silver birch leaves and Scots pine inflorescences (Fig. 4B).

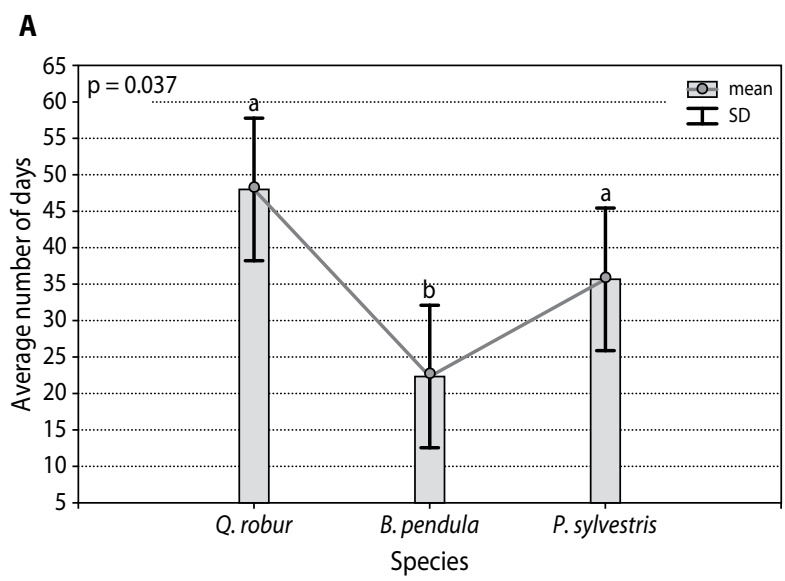

B

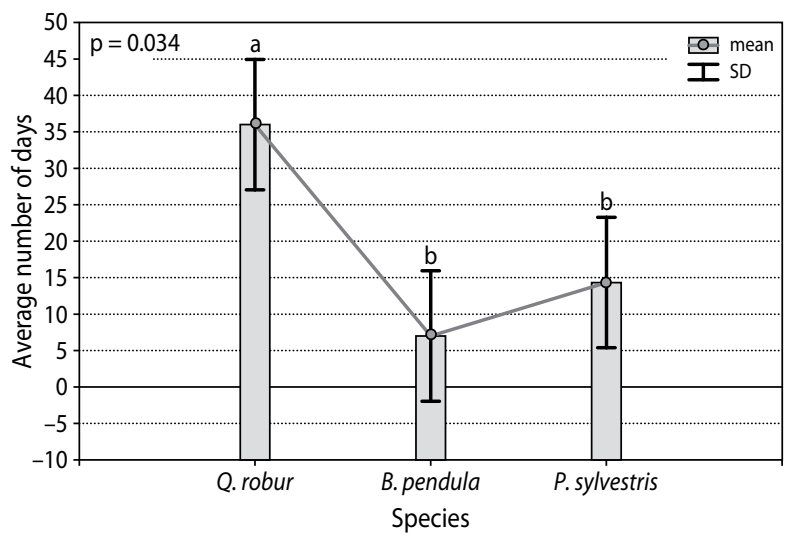

Figure 4. Average life span of common cockchafer adult females (A) and males (B) males in 2015

\section{Experimental year: 2016}

Forest cockchafer females observed in 2016 on the leaves of silver birch, pedunculate oak and red oak leaves survived 33 days. Comparatively the longest lived females on the leaves of small-leaved lime (7 weeks) (Fig. 5A). For the males, the most appropriate food that secured their longest life was oak leaves of (Fig. 5B). In comparison with other host plants test- ed, forest cockchafer males lived on the leaves of silver birch for the shortest time.

A

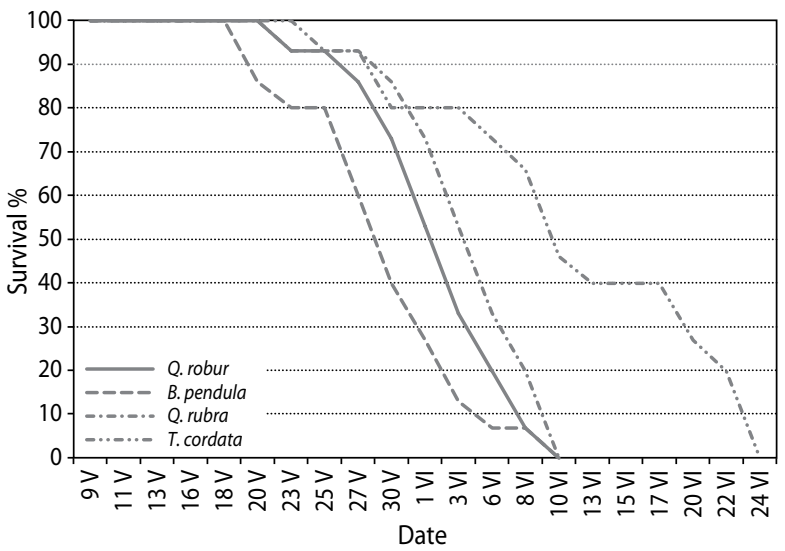

B

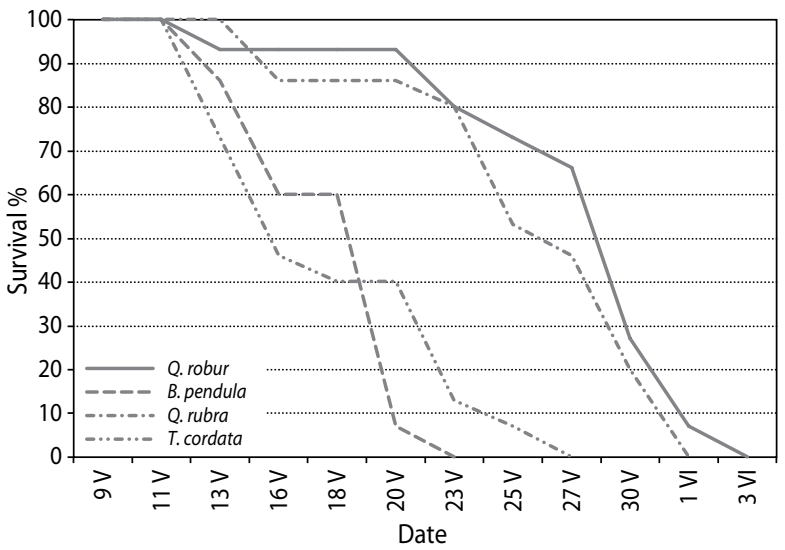

Figure 5. Survival of forest cockchafer adult females (A) and males (B) in 2016

The average life span of forest cockchafer females reared on the leaves of small-leaved lime was the longest and statistically different from that of the females feeding on other tested plant species (Fig. 6A). There were no statistically significant differences between the average life span of the females feeding on oak and silver birch leaves. The average life span of forest cockchafer males feeding on the leaves of pedunculate oak and red oak was the longest and significantly different from the average life span of the males feeding on birch and lime leaves (Fig. 6B). 
A

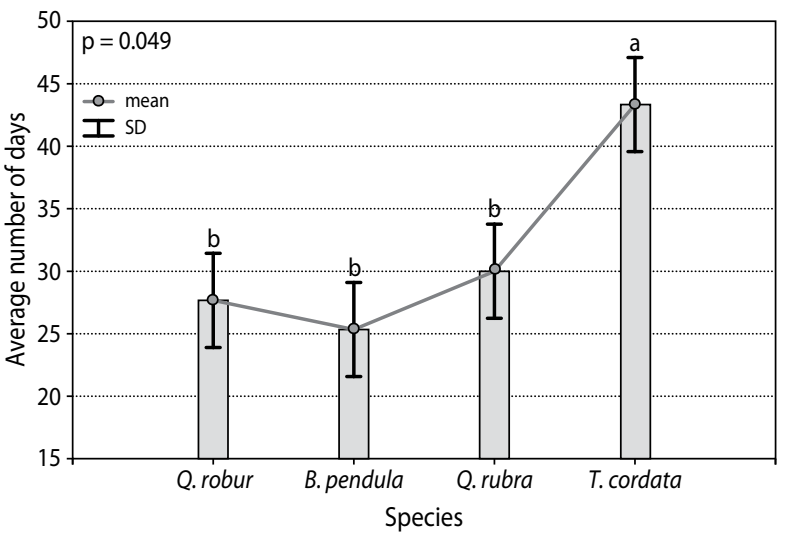

B

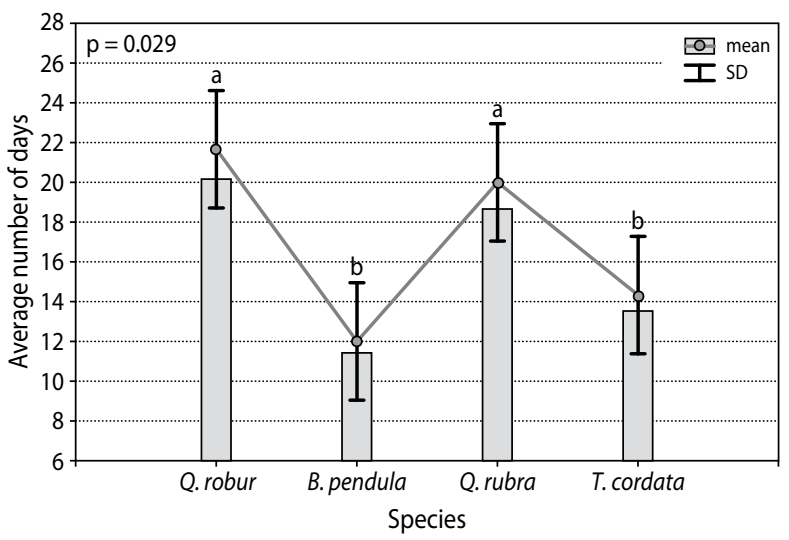

Figure 6. Average life span of forest cockchafer adult females (A) and males (B) in 2016

\section{Experimental year: 2017}

The results of the present study showed that forest cockchafer females reared on the leaves of pedunculate oak and silver birch lived comparatively the longest, however, adult mortality rate on these plant species differed substantially (Fig. 7A). On oak leaves, $100 \%$ of the observed females lived for more than 3 weeks, whereas mortality of the females fed on birch leaves was recorded already after 12 days of rearing. Forest cockchafer males lived the longest on the leaves of pedunculate oak -39 days, (Fig. 7B). On other plant species tested, the males lived for about 3 weeks.
A

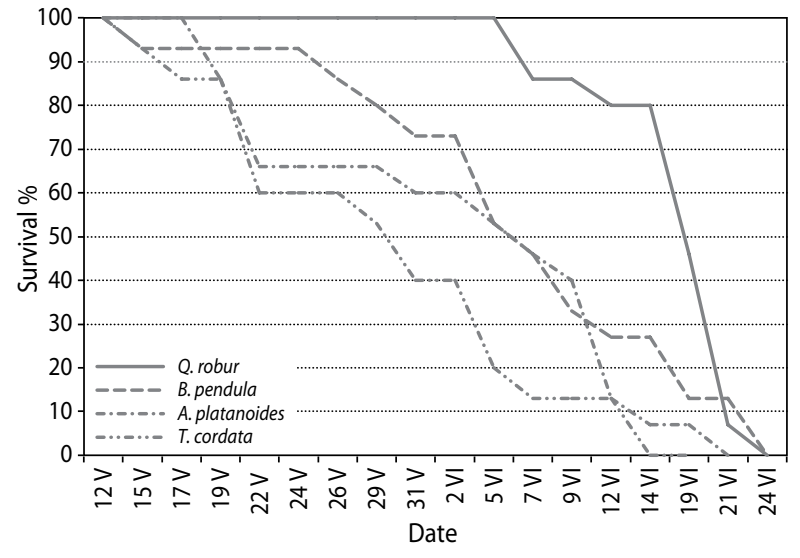

B

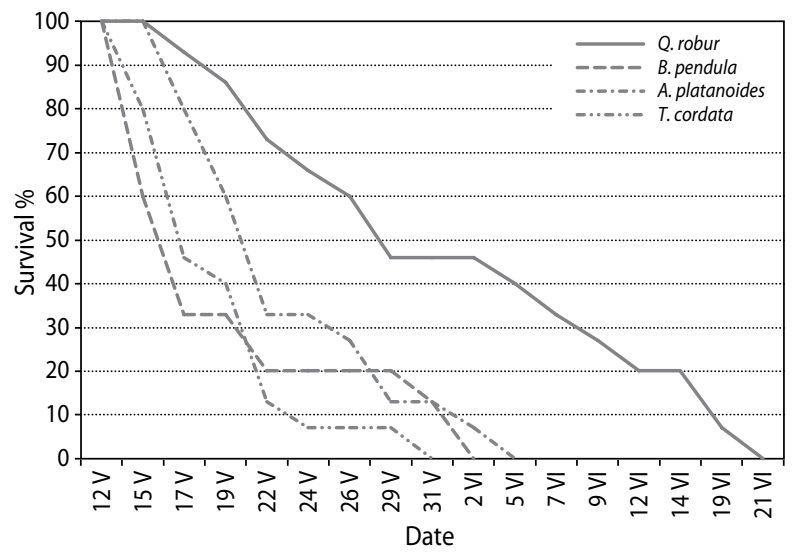

Figure 7. Survival of forest cockchafer adult females (A) and males (B) in 2017

The average life span of the females feeding on all the plant species studied in 2017 did not differ statistically (Fig. 8A). The average life span of the males feeding on the leaves of pedunculate oak did not differ statistically from the average life span of males feeding on Norway maple leaves (Fig. 8B). There were no statistically significant differences between the average life lengths of the males feeding on the leaves of silver birch and small-leaved lime. In general, the females and males feeding on the leaves of Norway maple, silver birch and small-leaved lime lived the shortest. 
A

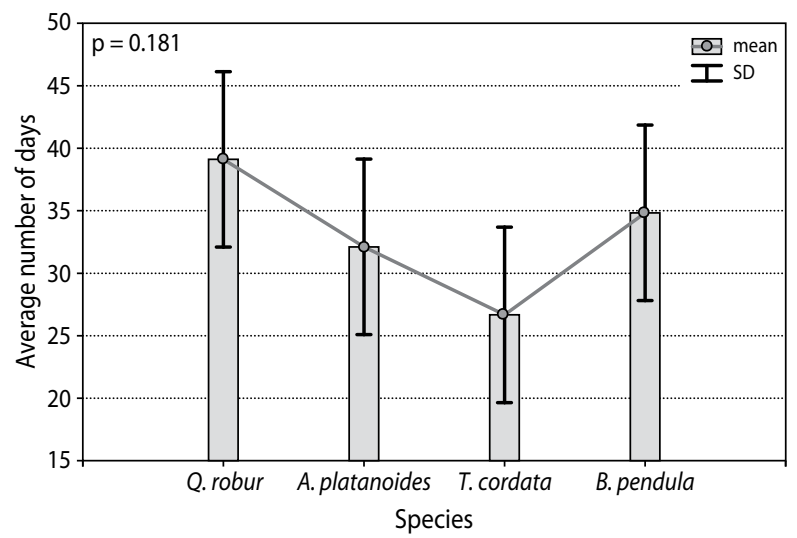

B

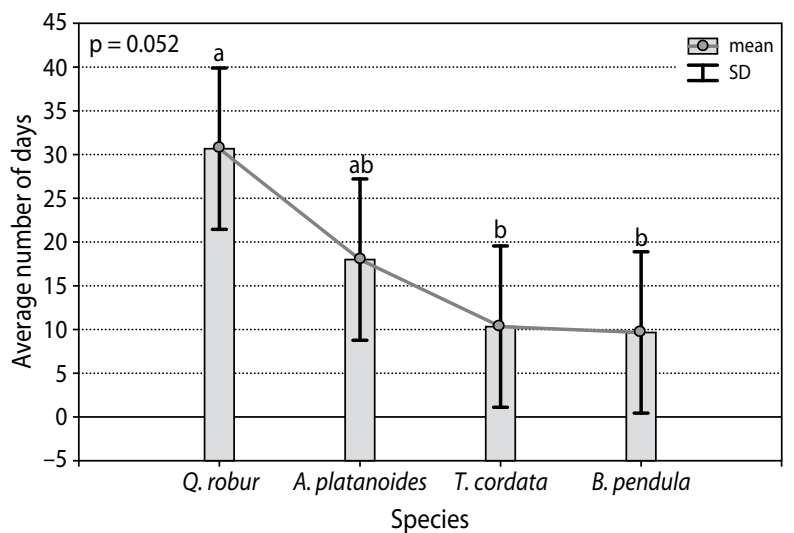

Figure 8. Average life span of forest cockchafer adult females (A) and males (B) in 2017

\section{Body weight gain in cockchafer adults after 1-week feeding}

Experimental year: 2015

In the period of 30 April and 7 May, the RGR value was positive only in the case of the forest cockchafer females feeding on the leaves of pedunculate oak, and it differed statistically from that in the females feeding on silver birch leaves (Fig. 9A). At the same time, weight loss was observed in the females feeding on Scots pine inflorescences.

In the same way, male RGR was positive only in the case of forest cockchafers feeding on pedunculate oak leaves, and it differed significantly when compared with RGR obtained in the males feeding on other plant species tested (Fig. 9B). No statistically significant differences were found between the RGR values observed in the males feeding on silver birch leaves and Scots pine inflorescences. The males feeding on Scots pine inflorescences showed the highest weight loss as compared with other host plants tested.

A

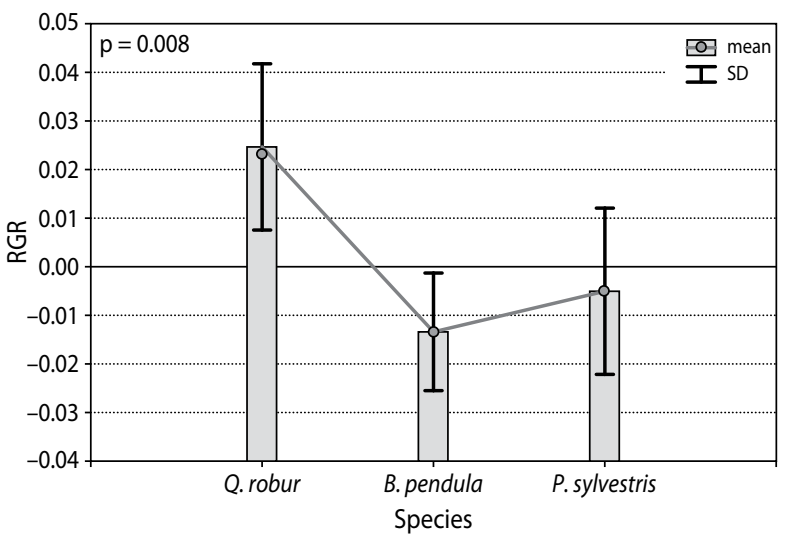

B

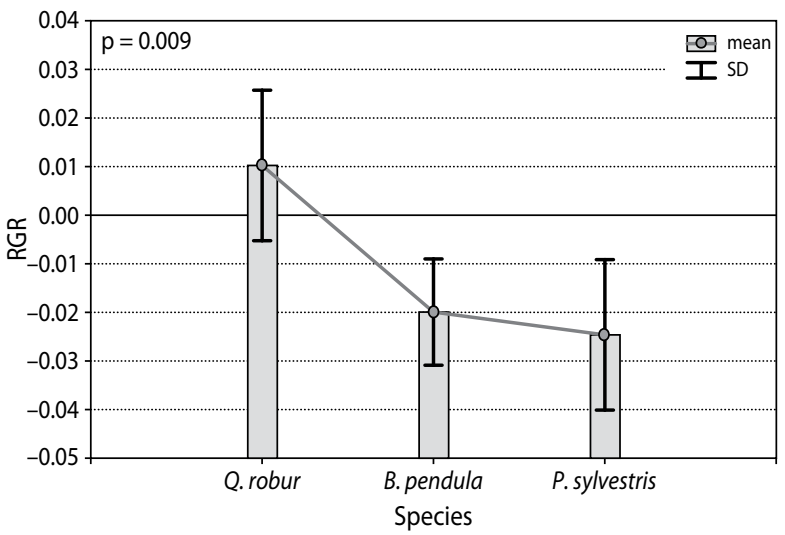

Figure 9. RGR of forest cockchafer females (A) and males (B) tested in 2015

In the period of 8 May to 15 May, RGR of common cockchafer females was positive in those feeding on pedunculate oak leaves and Scots pine inflorescences. The RGR values obtained were significantly different from RGR of females feeding on birch leaves (Fig. 10A).

At the same time, the RGR values observed in common cockchafer males was positive only in the case of the males feeding on pedunculate oak leaves (Fig. 10B). RGR values obtained in the males feeding on silver birch leaves and Scots pine inflorescences were negative. Males feeding on silver birch leaves lost more weight as compared with other host plants under the study. Yet, the differences found were not significant. 
A

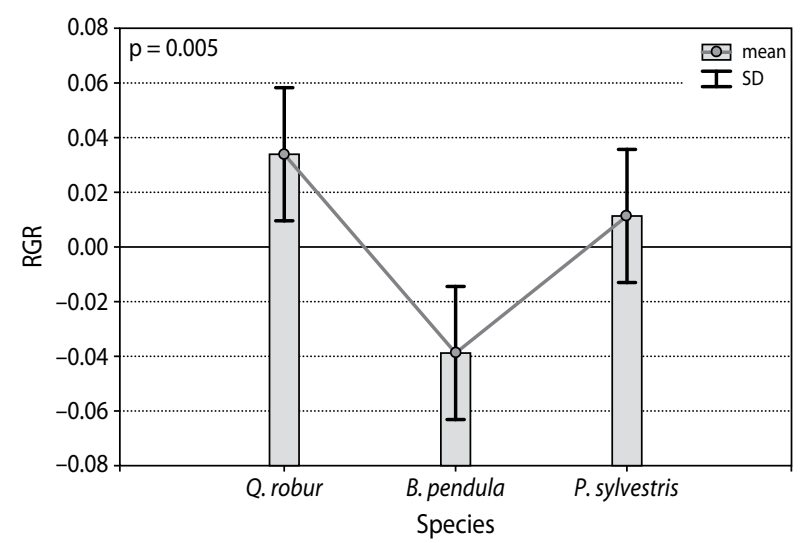

B

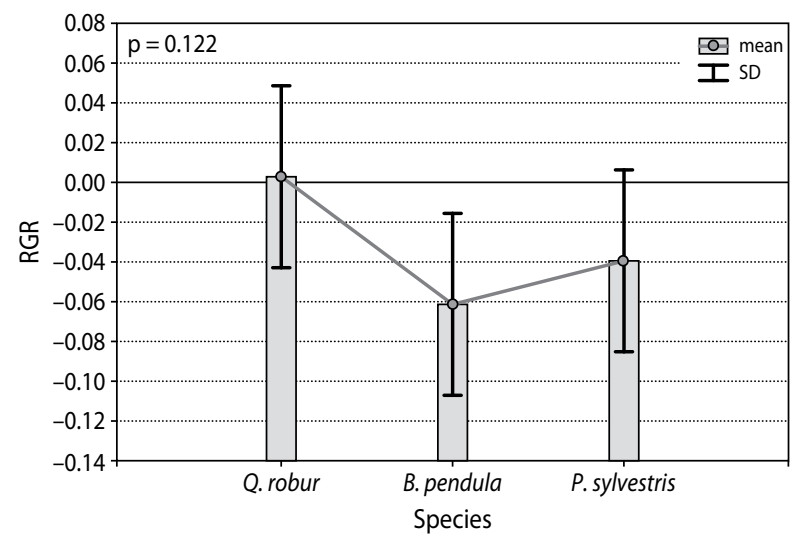

Figure 10. RGR of common cockchafer females (A) and males (B) tested in 2015

\section{Experimental year: 2016}

In the period from 9 May to 16 May, the RGR values obtained in forest cockchafer females were positive in those feeding on pedunculate oak and red oak leaves. The values obtained differed significantly from the negative RGR values observed in the females feeding on the leaves of silver birch and small-leaved lime (Fig. 11A).

Simultaneously, RGR values obtained in the case of forest cockchafer males were positive in the males feeding on pedunculate oak and red oak leaves (Fig. 11B). Negative RGR was found in the males feeding on the leaves of silver birch and small-leaved lime. These differences were not statistically significant.
A

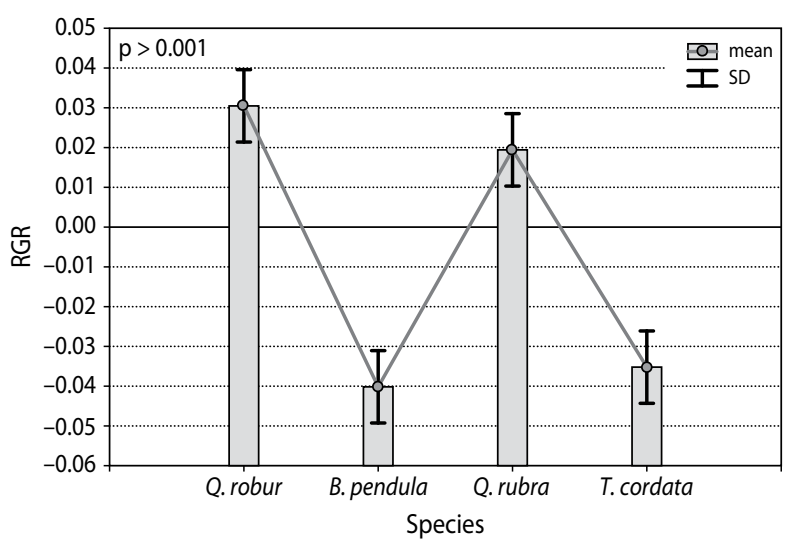

B

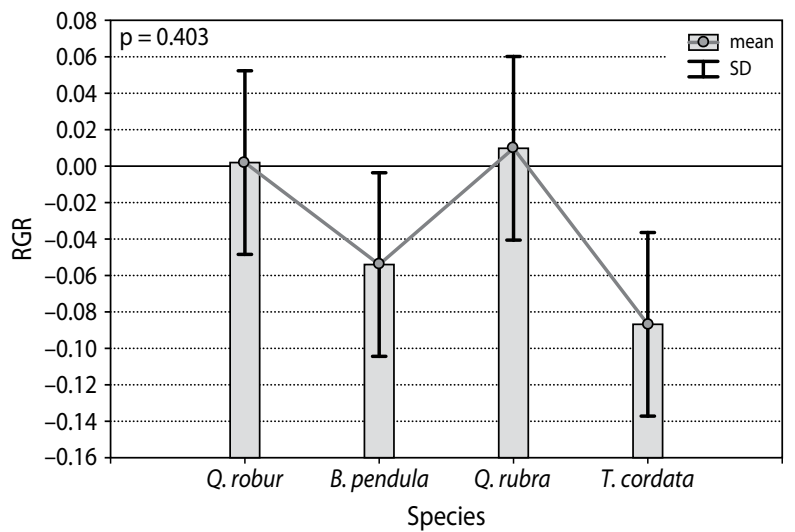

Figure 11. RGR of forest cockchafer females (A) and males (B) tested in 2016

\section{Experimental year: 2017}

From 12 May to 19 May, the highest RGR value was achieved by forest cockchafer females feeding on the leaves of pedunculate oak. The RGR values obtained in the females feeding on Norway maple leaves was positive (close to zero), whereas close to zero RGR values observed in the females feeding on silver birch leaves were negative (Fig. 12A). The differences between the RGR values found in the females feeding on oak, maple and birch leaves were not significant, but significantly different from RGR values in the females feeding on the leaves small-leaved lime.

The RGR values obtained in all the observed males feeding on the tested plants in 2017 were negative. The highest and nearest zero RGR values were observed in the males feeding on oak leaves (Fig. 12B). The males feeding on silver birch leaves reached comparatively 
the lowest RGR values and these differed significantly from those in the males feeding on other plant species tested.

A

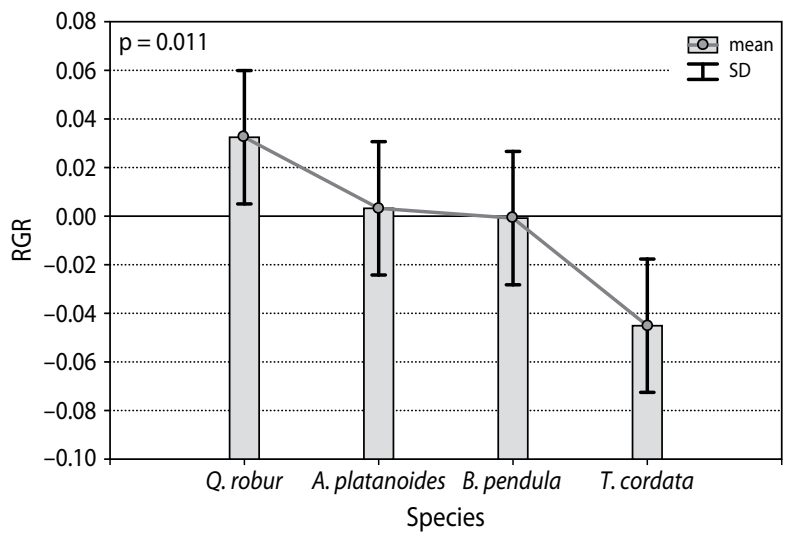

B

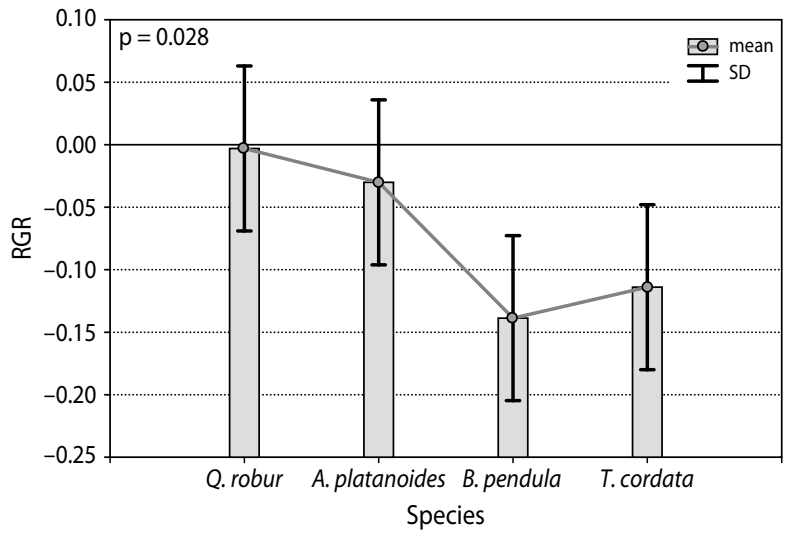

Figure 12. RGR of forest cockchafer females (A) and males (B) tested in 2016

\section{Female fertility}

In 2015, when provided pedunculate oak diet, forest cockchafer females laid eggs (in total 187) in all the experimental containers. The number of eggs laid by the females feeding on oak leaves differed significantly from the number of eggs laid by other examined females (Fig. 13A). There were no significant differences between the number of eggs laid by the females feeding on silver birch leaves and Scots pine inflorescences. Likewise, common cockchafer females who fed on oak leaves deposited comparatively the most eggs (in total 219), and this number differed significantly from the number of eggs laid by other examined females
(Fig. 13B). There were no significant differences found between the number of eggs laid by females feeding on silver birch leaves and pine inflorescences.

A

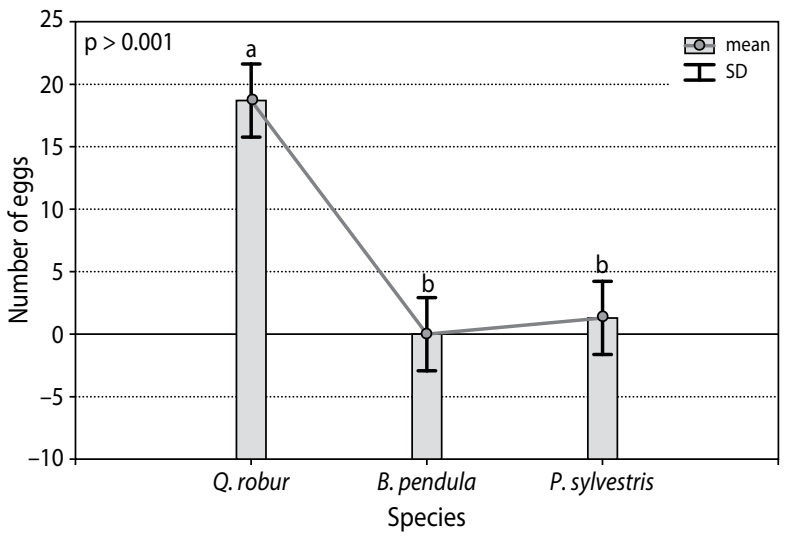

B

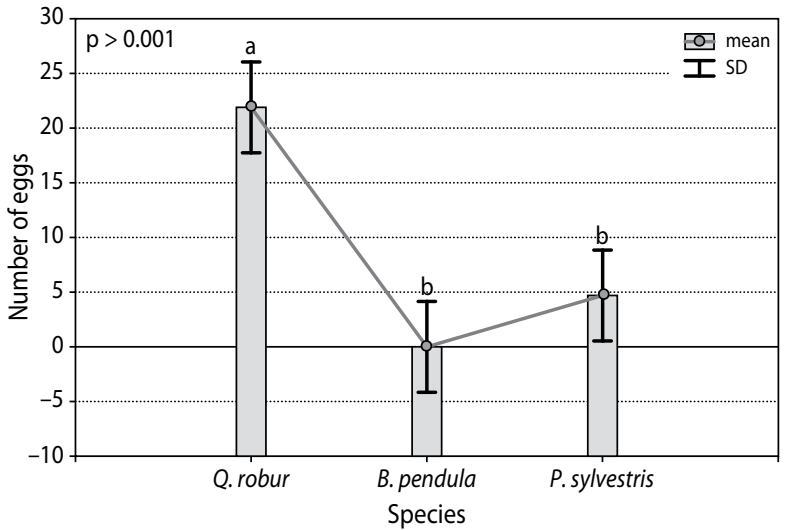

Figure 13. Number of eggs laid by M. hippocastani (A) and $M$. melolontha (B) females depending on the host plant tested in 2015

In 2016, forest cockchafer eggs were found in all the test containers with pedunculate oak and red oak diet (on average 21 eggs/female). The number of eggs laid by the females feeding on the leaves of oaks differed statistically from the number of eggs laid by the females feeding on other plant species examined (Fig. 14). There were no significant differences between the number of eggs laid by the females feeding on the leaves of silver birch and small-leaved lime.

In 2017, in total 194 eggs were laid in 9 containers with forest cockchafer females on pedunculate oak diet, however, no significant differences were found between this number and the number of eggs laid by the females 
feeding on Norway maple leaves (104 eggs). The number of eggs laid by the females feeding on oak leaves differed statistically from the number of eggs laid by the females feeding on silver birch leaves and small-leaved lime (Fig. 15). There were no significant differences between the number of eggs laid by the females feeding on the leaves of Norway maple, silver birch and smallleaved lime.

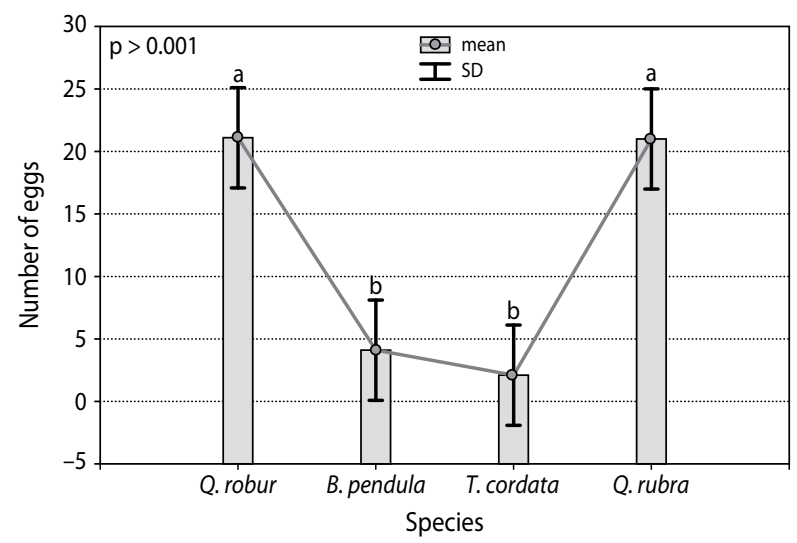

Figure 14. Number of eggs laid by M. hippocastani females depending on the host plant tested in 2016

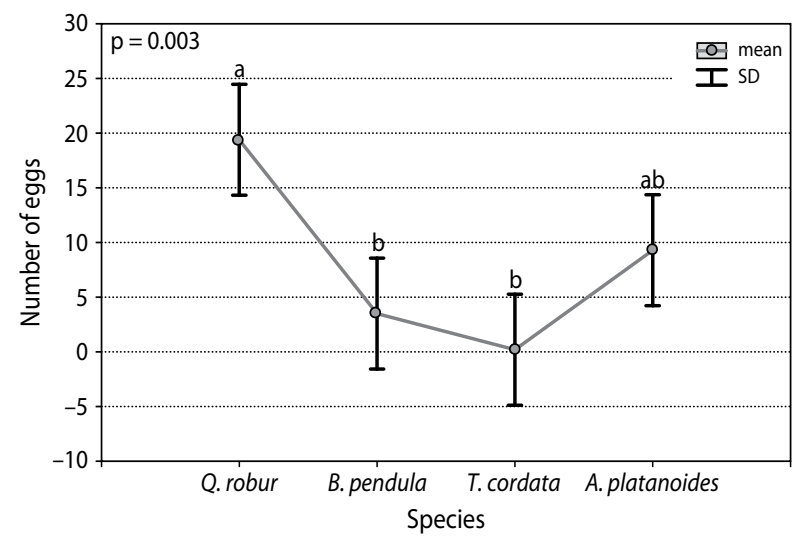

Figure 15. Number of eggs laid by M. hippocastani females depending on the host plant tested in 2017

\section{Discussion}

Nutritional preferences of adult cockchafers (M. melolontha and M. hippocastani) were studied using the leaves of silver birch, small-leaved lime, Norway maple and Scots pine inflorescences, as well as the leaves of pedunculate oak and red oak. The latter species was treated as the control both in the earlier studies carried out by Woreta and Sukovata (2010) and Woreta et al. (2016) and in the present study. When compared to the preceding studies, besides oak, the second re-examined tree species was silver birch due to the fact that previously obtained results raised some doubts. In all the previous and present experiments, the same methodology was used and pedunculate oak was always treated as the reference plant species.

Even though cockchafers are polyphagous and can feed on various host plants, not all of plants affect equally adult survival and the number of eggs laid by females. Previous studies (Woreta et al. 2016b) showed that food type was an important factor for cockchafers and had the crucial effects on their life processes. Some plants constitute valuable food for cockchafers, and other shorten their life span, reduce fertility, and in the extreme cases - can cause starvation. A great influence on the choice of host plant by insects have plant morphological features, such as the leaf size and thickness and the occurrence of hairs, furrows, thorns or wax coating on leaf surface (Malinowski 2008). Also, plant chemicals can have a luring or repellent effect on insects. In addition to biologically active compounds that fulfill important physiological functions in the plant, there also exist the so-called specific substances, which are usually secondary metabolites (Lewkowicz-Mosiej 2003). Many of the secondary metabolites exhibit severe toxicity to insects. These substances include glycosides, alkaloids, saponins, flavonoids, bitter compounds, tannins, organic acids (Sarwa 2001) and many other substances that have a negative effect on insect feeding (Harborne 1997). Glycosides and alkaloids are considered active substances with a strong action, which in high doses can cause poisoning. Flavonoids are plant tannins that are commonly found in relatively high concentrations in the leaves of woody plants and act as insect repellents (Harborne 1997).

Previously carried out studies (Woreta and Sukovata 2010; Woreta et al. 2016b) showed that the leaves of pedunculate and sessile oaks constituted full-value diet for forest and common cockchafers, beneficial for both their life span and body weight gain in the first week of adult life, as well as on the number of eggs laid by females. The present study confirmed the beneficial effect of pedunculate oak leaves on both studied cockchafer 
species. Furthermore, red oak leaves proved to be excellent food for forest cockchafer adults. Essentially, it can be assumed that the leaves of the three oak species growing in Poland (pedunculate, sessile and red) constitute a good source of food for common and forest cockchafer adults, as well as provide them with perfect conditions for further development (Woreta et al. 2016b). At the time when cockchafer adults emerge, oak leaves begin to grow. Young oak leaves are soft, consist in considerable amounts of amino acids and proteins but no virulent poisons (Kozłowski 2008). Adult cockchafers can successfully feed on oak leaves, which at that time contain lots of water and low amounts of tannins. With time, leaf tannin concentration increases, and then insects are repelled (Feeny 1970).

An interesting result of the previous studies (Woreta and Sukovata 2010; Woreta et al. 2016b), in contrast to literature data (Nunberg 1934; Sierpiński 1975), was the demonstration of the low nutritional value of silver birch for both common cockchafer and forest cockchafer adults. This result was confirmed by the present study and data obtained the years 2015 and 2016. Forest cockchafer adults who fed on silver birch leaves were characterized by a decrease in body weight in the first days of feeding, as well as poor female fertility. At the same time, common cockchafer adults did not like silver birch diet at all. The reason behind this phenomenon may be biologically active substances specific to silver birch (Polakowska 1982; Kosiński and KrzystakKosińska 2008). In birch leaves, there occur flavonoids which are the group of organic compounds fulfilling the function of natural insecticides and fungicides, along with saponins - classified as glycosides of high toxicity to insects. In 2017, forest cockchafer females feeding on silver birch leaves lived longer (on average 26 days) than it had been observed in the earlier studies. After a week of feeding, their average body mass gain was close to zero. Both in 2016 and 2017, fertility of the females feeding on silver birch leaves remained low. Three females out of ten laid a total of 35 eggs. Forest cockchafer males lived on silver birch diet no longer than 8 days and lost more weight than the males feeding on other tested plant species. Relatively longer life of the females and less important decrease in their body weight may have resulted from enhanced host plant condition due to much more rainfall in the spring of 2017, as compared to weather conditions prevailing in the previous years. In Poland, the average precipitation in April 2017 was $63.1 \mathrm{~mm}$ and in $2016-38.7 \mathrm{~mm}$ (Bulletin 2016, 2017). The content of water in the plant also depends on a degree of air saturation with vapor water (Duda and Gumiński 1974). Maybe the increased water content in silver birch leaves tested caused that forest cockchafer females more eagerly consumed silver birch diet. Birch, as a plant that develops leaves already in April, may serve as a temporary host plant for early emerging forest cockchafer adults, awaiting for the development of oak leaves or else - other preferred plants. Birch leaves definitely affect badly the development of common cockchafer adults. In the present study, both common cockchafer females and males who fed on silver birch had the shortest life span and the lowest gain of body weight when compared to other tested host plants. What is more, the females of this species proved to be infertile when feeding on silver birch.

Scots pine inflorescences can be used as food only by common cockchafer, as at the time of forest cockchafer emergence (usually at the end of April), Scots pine has no developed flowers. For this reason, in the present study, forest cockchafer adults collected in the field were stored in a climatic chamber for a week, until Scots pine flowers developed. Under the conditions of the present study, forest cockchafer females who fed on Scots pine inflorescences lived for a relatively short time, lost weight and only 1female of 10 laid 13 eggs. The males lived shortly and also lost weight. In contrast, common cockchafer females and males feeding on Scots pine inflorescences were the second in order in terms of the life span, when compared with all the host plants examined. Females lived on average over 30 days and increased their body weight in the first week of observations. Three females laid in total 47 eggs. The average body weight of males decreased after the first week of feeding. In plant pollen, there occur first of all sugars $(33.7 \%)$ and then - proteins, amino acids (23.9\%) and cellulose (22.4\%). Next in order, there are: water $(9.5 \%)$, lipids and fatty acids $(5.4 \%)$, bioelements (1.3\%), polyphenolic and triterpene compounds $(1.2 \%)$, as well as vitamins $(0.2 \%)$. All the aforementioned components give a total value of $97.6 \%$ (Kędzia 2008). Our study showed that nutritious pollen of Scots pine flowers may be an appropriate food for common cockchafer, and in particular for females of this species. According to Niemczyk (2017), Scots pine does not constitute any 
food base for adult cockchafers, thus, it is not a tree species whose high share in Poland's forest stands can be the reason for the occurrence of grubs in the soil.

Another host plant tested for 2 years was smallleaved lime. In 2016, forest cockchafer females who fed on this plant lived comparatively the longest - on average 34.2 days, whereas males' life span was the shortest - on average 9.7 days. Both females and males lost weight after a week of feeding on small-leaved lime. One of ten tested females laid 21 eggs. In 2017, forest cockchafer females and males lived comparatively the shortest when fed on small-leaved lime. All the cockchafers examined lost weight and only one female laid 2 eggs. The reason behind the result obtained may be the fact that the leaves of small-leaved lime contain, among others: flavonoids, essential oil, mucus compounds, phytosterol, tannins, organic acids (Kosiński and Krzystak-Kosińska 2008). Phytosterols produced by plants are a structural element of cellular and cytoplasmic membranes. These compounds participate in the regulation of intracellular processes and act as defense substances against herbivores (Nowak 2011). Flavonoids and tannins have a repellent effect on insects.

The last host plant examined under the conditions of the present study was Norway maple. The results showed that Norway maple leaves constituted less valuable food for cockchafers when compared with oak leaves, yet - much better than other plant species tested in 2017. Females feeding on maple leaves lived on average 22.5 days and on oak leaves - 36.3 days. The average body weight of females after a week of feeding increased slightly and 6 females out of 10 laid a total of 104 eggs. Presumably, likewise in oak leaves, also in Norway maple leaves, there are no strong secondary metabolites acting as insect repellents. Therefore, Norway maple constitutes quite valuable diet for both forest and common cockchafer adults (Sierpiński 1975).

During the studies carried out, there was sometimes observed that some females lived much longer in comparison with other females feeding on the host plant containing poisonous and repellent substances. This was the case in 2016, when forest cockchafer females fed on small-leaved lime leaves and lived from 9 May to 22 June (44 days). The average life span of forest cockchafer females feeding on small-leaved lime was 34.2 days, whereas those feeding on the leaves of red oak lived on average 26.6 days, and in the case of pedunculate oak - 24.4 (10 days shorter when compared with small-leaved lime). Forest cockchafer males lived on average only 9.7 days when fed with small-leaved lime leaves. In 2013 (Woreta et al. 2016b), forest cockchafer females lived on rowan leaves for 65 days (from 30 April to 5 July). Then, the average life span of females was 49.9 days, and males only 18.8 days. Females who fed on the leaves of pedunculate oak survived for on average 34.9 days ( 15 days shorter life span as compared to rowan). In contrast, males on the oak leaves lived the longest (25.7 days) when compared to other males feeding on the plants tested in 2013.

According to Harborne (1997), insects can develop in the dynamic environment due to the fact that they build up mechanisms that allow to bypass plant defense mechanisms. Insects can adapt biochemically or anatomically to the absorption/digestion of new plant foods. They can even develop new eating habits or new taste preferences. In addition, they are able to develop mechanisms of detoxification and can neutralize toxicity of poisonous substances to cease feeding barriers. Such detoxification consists mainly of chemical modification of the toxin in vivo and its transformation into a non-toxic complex or its storage in special storage tissues in insect organism. Perhaps different behaviors of some females observed in the carried out studies resulted from wide capability of insects to adapt to the changing natural environment

\section{Conclusion}

The 3-year study aimed at assessing food type effects on adult cockchafer life span, weight gain in the first week after emergence, as well as female fertility. Adult cockchafer nutritional preferences were examined using as food the leaves of silver birch, pedunculate and red oaks, Norway maple, small-leaved lime, as well as Scots pine inflorescences. In 2015 it was possible to collect specimens of two cockchafer species (M. melolontha and M. hippocastani) under field conditions. In the following experimental years, only forest cockchafer adults were available for testing. In 2015, M. melolontha adults fed on Scots pine inflorescences, as well as the leaves of silver birch and pedunculate oak (the reference host plant during the whole period of observations). The 
study results showed that the most beneficial food for both cockchafer species tested as regards their life span, body weight gain and female fertility was pedunculate oak diet. In the same way, red oak diet was beneficial for M. hippocastani adults. Pollen from Scots pine flowers proved to be appropriate diet for M. melolontha females. Males of both studied cockchafer species lived relatively shortly and lost weight. Norway maple leaves turned out to be the right food for $M$. hippocastani adults. In the case of the latter species, silver birch diet caused adult weight loss, shorter life span and low female fertility. M. melolontha showed no preference as to silver birch leaves. M. hippocastani adults feeding on the leaves of small-leaved lime were characterized by the short life span, weight loss in the first days after emergence, as well as poor female fertility.

\section{SOURCES OF FINANCING}

The study was financed from the funds of the Ministry of Science and Higher Education granted for the statutory activity of IBL (Grant no. 240320).

\section{References}

Biuletyn Państwowej Służby Hydrologiczno-Meteorologicznej. IMiGW, kwiecień, 2016, 2017.

Duda, J., Gumiński, S. 1974. Fizjologia roślin. PWN, Warszawa.

Feeny, P. 1970. Seasonal Changes in Oak Leaf Tannins and Nutrients as a Cause of Spring Feeding by Winter Moth Caterpillars. Ecology, 51 (4), 565-581.

Harborne, J.B. 1997. Ekologia biochemiczna. Wydawnictwo Naukowe PWN, Warszawa.

Kędzia, B. 2008. Skład chemiczny i adaptogenne działanie pszczelego pyłku kwiatowego. Cz. 1. Skład chemiczny. Postępy Fitoterapii, 1, 47-58.

Kosiński, M., Krzyściak-Kosińska, R. 2008. Atlas ziół. Pascal sp. z o.o., Bielsko Biała.

Kozłowski, M.W. 2008. Wyspy obfitości. Matecznik Białowieski, 1, 8-10.

Lazarević, J., Perić-Mataruga, V., Stojković, B., Tucić, N. 2002. Adaptation of the gypsy moth to an unsuitable host plant. Entomologia Experimentalis et Applicata, 102, 75-86.
Lewkowicz-Mosiej, T. 2003. Leksykon roślin leczniczych. Świat Książki, Warszawa.

Maciejowski, K. 1936. Zwalczanie chrabąszcza w lasach państwowych. Las Polski, 12, 33-40.

Malinowski, H. 2003. Odporność owadów na insektycydy. Wieś Jutra, Warszawa.

Malinowski, H. 2008. Strategie obronne roślin drzewiastych przed szkodliwymi owadami. Leśne Prace Badawcze, 69 (2), 165-173.

Malinowski, H. 2010. Niechemiczne metody ochrony szkółek i upraw leśnych przed owadami uszkadzającymi systemy korzeniowe drzew i krzewów. Instytut Badawczy Leśnictwa, Sękocin.

Niemczyk, M. 2017. Ekoklimateczne uwarunkowania występowania chrabąszczy z rodzaju Melolontha sp. w ogniskach gradacyjnych w środkowej i południowo wschodniej Polsce. Instytut Badawczy Leśnictwa, Sękocin.

Nowak, A. 2011. Fitosterole w codziennej diecie. Postępy Fitoterapii, 1, 48-51.

Nunberg, M. 1934. Chrabąszcz i jego zwalczanie. Serja $C$ - ulotki $i$ wydawnictwa popularne, Instytut Badawczy Lasów Państwowych w Warszawie, 5, $1-20$.

Petrykowski, A. 1937. Zbiór chrabąszcza. Niwa Leśna, 4.

Polakowska, M. 1982. Leśne rośliny zielarskie. PWRiL, Warszawa.

Remiszewski, K. 1899. Quo usque tandem Melolontha? Sylwan, 136-141.

Różyński, F. 1926. W sprawie walki z chrabąszczem majowym. Przeglad leśniczy, 1, 32-38.

Sarwa, A. 2001. Wielki leksykon roślin leczniczych. Książka i Wiedza, Warszawa.

Sierpiński, Z. 1975. Ważniejsze owady - szkodniki korzeni drzew i krzewów leśnych. PWRiL, Warszawa.

Skrzecz, I., Sowińska, A., Janiszewski, W. 2014. Wpływ antyfidantów botanicznych na rozwój chrząszczy chrabąszcza majowego. Sylwan, 158 (10), 779- 786.

Woreta, D. 1994. Zmiany występowania szkodników korzeni drzew i krzewów leśnych w latach 1961-1993. Sylwan, 5, 37-41.

Woreta, D. 1997. Możliwości ograniczania szkód powodowanych przez pędraki chrabąszczowatych $(M e-$ lolonthinae) metodami niechemicznymi. Sylwan, 5 , 29-39. 
Woreta, D., Sukovata, L. 2010. Wpływ pokarmu na rozwój chrabąszcza kasztanowca (Melolontha hippocastani F.) (Coleoptera, Melolonthidae). Leśne Prace Badawcze, 71 (2), 195-199.

Woreta, D. 2015. Control of cockchafer Melolontha spp. grubs - a review of methods. Folia Forestalia Polonica, Ser. A-Forestry, 57 (1), 33-41.
Woreta, D. 2016a. Reduction of population numbers of Melolontha spp. adults - a review of methods. Folia Forestalia Polonica, Ser. A - Forestry, 58 (2), 87-95. Woreta, D., Lipiński, S., Wolski, R. 2016b. Wpływ pokarmu na imagines chrabąszczy Melolontha melolontha i M. hippocastani. Leśne Prace Badawcze, 77 (1), 14-21. 